\title{
SERGEI MIRONENKO JA POLIITTINEN KRITIIKKI
}

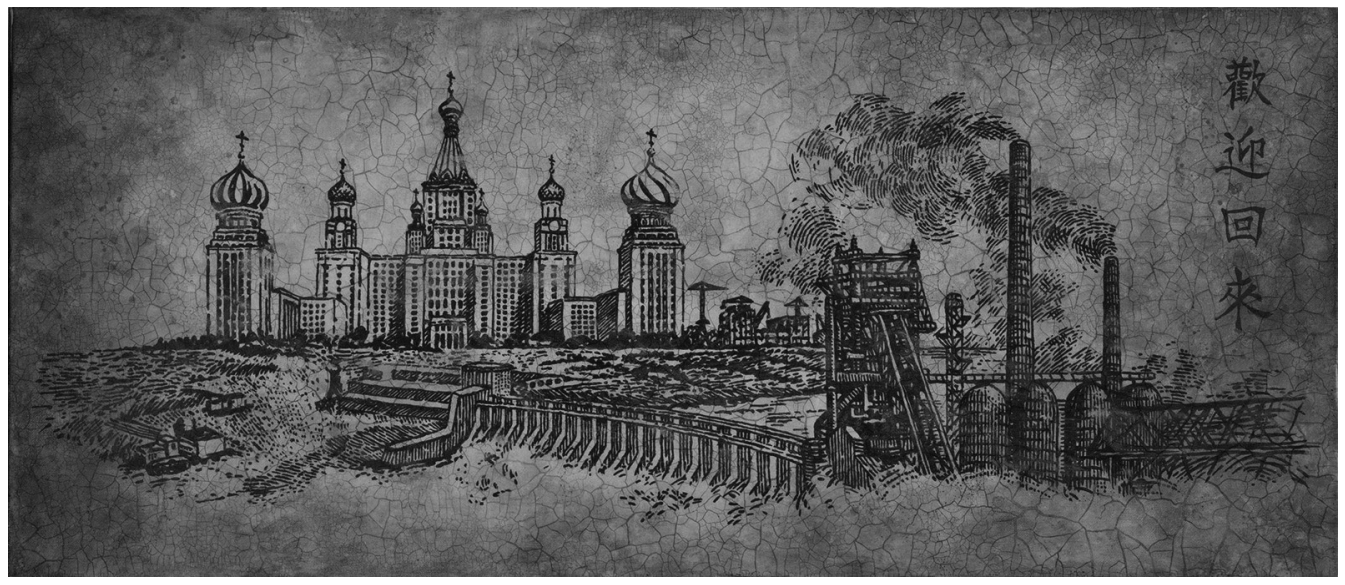

SERGEI MIRONENKO: TERVETULOA, 2013. MONTAASI, TULOSTUS ERILAISILLE PINNOILLE.

Sergei Mironenko (s. 1959) on monipuolinen moskovalainen taiteilija, joka on työskennellyt poliittisena käsitetaiteilijana, sisustusarkkitehtina, graafikkona, kuraattorina ja liikemiehenä. Nämä erilaiset roolit ovat olleet hänen vastauksiaan nopeasti muuttuneessa poliittisessa ja taloudellisessa tilanteessa Neuvostoliitossa ja Venäjällä.

Suomessa 1988 Mironenko osallistui Neuvostoliittolaisen avantgardetaiteen festivaaliin Imatralla, jossa hän esiintyi Neuvostoliiton ensimmäisenä vapaana presidenttiehdokkaana. Hänen töitään nähtiin myös Helsingissä 1980-luvun lopulla. Agitpunkt-näyttelystään Galerie Pelinissä 1989 hän rakensi neuvostoliittolaisen poliittisen tiedotuskeskuksen parodian.

Moskovassa Mironenko oli aloitteentekijä, kun vanha, remonttia odottanut asuinkerrostalo Fumanny-kujalla muutettiin taiteilijoiden työhuoneiksi 1986. Tästä underground-taiteilijoiden yhteisöstä kehittyi nopeasti Moskovan nykytaiteen keskus useaksi vuodeksi.

Sisustusarkkitehti-, muotoilija- ja liikemiesvuosien jälkeen 2010-luvun taitteesta lähtien Mironenko on keskittynyt taiteelliseen toimintaansa. Uusimmissa teoksissaan hän ottaa terävästi kantaa Venäjän vallitsevaan poliittiseen tilanteeseen. Hän ei voi hyväksyä Putinin imperialistista Krimin valloitusta eikä sotilaallista osallistumista Ukrainan tapahtumiin. Ortodoksisen kirkon vaikutukseen nojautuva putinistinen ideologia on Mironenkon mukaan tunkeutunut myös yliopistoopetukseen ja tieteelliseen tutkimukseen ja vaarantaa tieteen riippumattomuuden.

Mironenko arvioi, että kolmasosa Moskovan taiteilijoista ja intellektuelleista on taipuvaista myötäilemään Putinin pyrkimyksiä, samalla kun kaksi kolmasosaa kyseenalaistaa ne. Nykytilanteen erikoinen piirre on, että uusvasemmistolaiset taiteilijat, jotka ovat Mironenkoa nuorempia eivätkä ole kokeneet neuvostoaikaa, potevat nostalgiaa ja ihannoivat Neuvostoliittoa ja samalla myös sympatisoivat Putinin politiikkaa. Pietarilainen taiteilija Dimitri Vilenski on näistä yksi tunnetuimpia; Suomessakin hän on luennoinut Kuvataideakatemian vieraana. Mironenko sanoutuu jyrkästi irti sekä Putinin politiikasta että uudesta nostalgiasta. 